\title{
Guided discovery berbantuan virtual lab untuk meningkatkan keterampilan proses sains dan sikap ilmiah
}

\author{
Fathiah Alatas $^{1 *}$, Willa Hikma Sakina ${ }^{2}$ \\ Program Studi Pendidikan Fisika Universitas Islam Negeri Syarif Hidayatullah Jakarta, Jakarta, DKI \\ Jakarta, Indonesia \\ *Coressponding author email: $\underline{\text { fathiah.alatas@ } @ \text { uinjkt.ac.id }}$
}

\begin{tabular}{ll}
\hline Artikel info \\
\hline Received : 20 June 2019 \\
Revised $\quad: 04$ November 2019 \\
Accepted $: 07$ November 2019
\end{tabular}

Kata kunci:

Guided discovery learning

Intelegensi siswa

Keterampilan proses sains

Sikap ilmiah

Virtual lab

\begin{abstract}
ABSTRAK
Virtual lab dapat memberikan pengalaman belajar nyata melalui simulasi dan kegiatan berbantuan komputer. Penelitian ini bertujuan untuk meningkatkan keterampilan proses sains dan sikap ilmiah berdasarkan IQ siswa pada konsep gerak harmonik sederhana melalui model guided discovery learning berbantuan virtual lab pada materi gerak harmonik sederhana. Penelitian ini dilakukan di kelas X IPA 1 SMA N 4 Tangerang Selatan. Metode kuasi eksperimen dengan desain nonequivalent control group digunakan dalam penelitian ini. Berdasarkan observasi, keterampilan proses sains siswa tertinggi yaitu aspek mengajukan pertanyaan dan rendah pada aspek berhipotesis. Kelompok siswa dengan IQ rendah dan sedang menunjukkan sikap ilmiah paling tinggi pada aspek berpikir terbuka dan bekerja sama sedangkan kelompok IQ tinggi yaitu dan pada aspek sikap penemuan serta kreativitas. Dengan demikian, model guided discovery learning berbantuan virtual lab dapat meningkatkan keterampilan proses sains siswa pada seluruh kelompok IQ.
\end{abstract}

\section{ABSTRACT}

Keywords:

Guided discovery learning

Student intelligence

Scientific attitude

Science process skill

Virtual lab

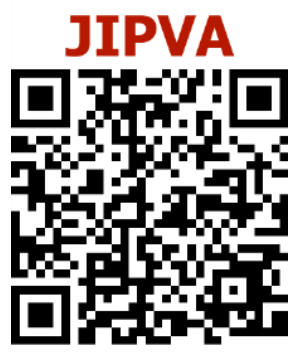

Guided discovery learning models with virtual laboratorium to improve science process skill and scientific attitude. Virtual lab gives real experience through simulation and activity based on computer. The aim of this research was to improve science process skill and scientific attitudes based on IQ level students on the concept of simple harmonic motion through guided discovery learning models with virtual laboratory. this research was conducted at X IPA-1 SMA N 4 South Tangerang. The research method used was a quasi-experimental research design with nonequivalent control group design. Based on observation of the student'ss science process skills, asking questions aspects is high and hypothesizing aspect is the lowest. The scientific attitude of students in low and moderate IQ level group was highest in the aspects of open thinking and working together while the high IQ level groups in discovery and creativity aspect. Thus, guided discovery learning with virtual lab can improve students' science process skills in all IQ level groups.

\section{https://doi.org/10.31331/jipva.v3i2.864}

How to Cite: Alatas, F.., \& Sakina, W. H. (2019). Guided discovery berbantuan virtual lab untuk meningkatkan keterampilan proses sains dan sikap ilmiah. JIPVA (Jurnal Pendidikan IPA Veteran), 3(2), 138-148. doi: https://doi.org/10.31331/jipva.v3i2.864

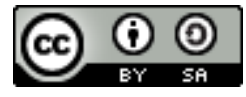




\section{PENDAHULUAN}

Penerapan pendekatan ilmiah (scientific approach) dalam kurikulum 2013 menekankan pada proses pembelajaran (Nuzulia, Adlim, \& Nurmaliah, 2017). Proses pembelajaran siswa harus mengintergrasikan keterampilan, pengetahuan dan sikap (Zeidan \& Jayosi, 2015). Pendekatan ilmiah dalam pembelajaran IPA dapat diterapkan melalui keterampilan proses sains (KPS) (Nuzulia et al., 2017). KPS merupakan indikator penting dalam mentransfer pengetahuan yang diperlukan untuk memecahkan masalah dan dapat memperoleh pengalaman dalam eksperimen (E. Wulandari, Suliyanah, \& Rohmawati, 2017). KPS meliputi merumuskan hipotesis, memprediksi, menemukan pola dan hubungan variabel (Hannasari, Harahap, \& Sinulingga, 2017). Seseorang yang telah mempelajari sains dalam merespon, menanggapi dan berperilaku berdasarkan ilmu pengetahuan dan etika ilmiah akan memiliki sikap ilmiah (Malinda, Rohadi, \& Medriati, 2017).

Proses pembelajaran fisika belum maksimal dalam menguasai dan berlatih KPS siswa pada kurikulum 2013 (Rahayu \& Admoko, 2016; Ramayanti, Utari, \& Saepuzaman, 2017; Rismawati, Sinon, Yusuf, \& Widyaningsih, 2017). KPS siswa yang belum dikuasai antara lain membuat hipotesis, mengidentifikasi variabel, menganalisis data, memprediksi dan membuat kesimpulan (Handayani, Arifuddin, \& Misbah, 2017; Hidayatulloh, 2015). Permasalahan serupa juga terjadi di SMAN 4 Tangerang Selatan. Berdasarkan hasil studi pendahuluan, KPS siswa kurang dilatih karena siswa belum berperan aktif disebabkan pembelajaran teacher center. Astra \& Wahidah (2017) menyatakan bahwa pembelajaran di kelas masih bersifat teacher center dan membuat siswa cenderung pasif, sehingga KPS siswa dalam kategori kurang. Siswono (2017) dalam penelitiannya menyatakan bahwa KPS merupakan faktor yang mempengaruhi rendahnya hasil belajar siswa. Penelitian lain menyatakan bahwa KPS di sekolah menengah atas masih dalam tingkat rendah, dikarenakan siswa tidak biasa untuk melakukan eksperimen dalam belajar fisika (Sahhyar \& Nasution, 2017) terutama pada materi gerak harmonik sederhana masih memiliki rata-rata yang rendah, nilai siswa masih di bawah rata-rata KKM yaitu 75. Data nilai salah satu kelas X MIPA pada materi gerak harmonik sederhana menyatakan bahwa 57,14\% siswa tidak tuntas. Konsep gerak harmonik sederhana dianggap sebagai konsep yang relative kompleks dipahami oleh siswa (Iradat \& Alatas, 2017).

Berdasarkan permasalah di atas, KPS siswa dapat dilatih dan dikembangkan melalui model pembelajaran yang memberikan pengaruh signifikan terhadap KPS siswa yaitu guided discovery (penemuan terbimbing) (Dewi, Doyan, \& Soeprianto, 2017; Maharani \& Hardini, 2017; Miftah, 2016). Model ini mengajak siswa berpartisipasi secara aktif dalam pembelajaran dan meningkatkan hasil belajar (Alatas, Pohan, \& Sulukin Nisa, 2018; Haryati, Manurung, \& Gultom, 2017). Penemuan terbimbing (guided discovery) merupakan contoh dari pembelajaran konstruktivisme. Konstruktivisme menunjukkan bahwa siswa membangun pengetahuan dari pengalaman mereka sendiri didasarkan adanya fakta, keterampilan dan pengetahuan. (Akinbobola \& Afolabi, 2010). Menurut Zunita dkk, model pembelajaran guided discovery yang menitik beratkan pada aktifitas siswa dalam menemukan sendiri konsep dan guru bertindak sebagai pembimbing dan fasilitator (Zunita, Dewi, \& Giarti, 2018). Pembelajaran menjadi efektif dan sangat berdampak untuk meningkatkan pemahaman konsep 
siswa (Hayati, Bintari, \& Sukaesih, 2018) serta KPS dapat dilatih dan hasil belajar siswa menjadi meningkat (Susilaningrum, Santosa, \& Ariyanto, 2017).

Salah satu tahapan dalam guided discovery learning yaitu eksplorasi yang dapat dilakukan melalui kegiatan percobaan di laboratorium (Habibbulloh, Jatmiko, \& Widodo, 2017) untuk memberikan kesempatan kepada siswa mengkonstruksi pemahaman mereka mengenai konsep gerak harmonik sederhana. Penerapan pembelajaran guided discovery sangat cocok menggunakan program simulasi komputer (Hariyanto, 2016) yang dianggap lebih efisien. Simulasi berbentuk perangkat lunak (software) yang di operasikan dengan komputer dan dapat mensimulasikan kegiatan dilaboratorium seakan-akan pengguna berada pada laboratorium yang sebenarnya disebut virtual lab (Al-Fajri, Alatas, \& Daryono, 2016). Virtual lab memberikan pengalaman langsung untuk melakukan percobaan dalam menemukan sendiri konsep-konsep fisika (Sari, Gunawan, \& Harjono, 2016). Virtual lab memberikan kesempatan siswa untuk membangun dan memahami konsep yang sulit menjadi lebih mudah (Bajpai \& Kumar, 2015). Peran teknologi mendukung proses belajar mengajar di era digital ini karena peran tersebut membantu siswa untuk menjadi pembelajar yang mandiri (Liao, Loures, Deschamps, Brezinski, \& Venâncio, 2018). Pembelajaran menggunakan teknologi merupakan pengaruh dari revolusi industri 4.0 dalam bidang pendidikan (Hussin, 2018). Ranjan (2017) dalam penelitiannya menyatakan bahwa virtual lab memiliki peran yang aktif dan signifikan karena penting untuk mengembangkan keterampilan proses sains siswa. Oleh karena itu, virtual lab merupakan salah satu media pembelajaran yang dapat diterapkan dalam proses pembelajaran fisika karena mampu memberikan kesempatan kepada siswa untuk memahami konsep gerak harmonik sederhana yang relatif kompleks dan siswa mengalami langsung, serta menemukan sendiri. Selain itu, virtual lab dapat meningkatkan KPS siswa dan mengembangkan sikap ilmiah.

Beberapa penelitian terdahulu telah banyak merekomendasikan guided discovery learning dengan bantuan virtual lab (Habibbulloh et al., 2017; Hermansyah, Gunawan, Harjono, \& Adawiyah, 2019) pada materi gerak harmonik sederhana (Price \& Price-mohr, 2019) tetapi belum dapat mengungkapkan implementasi pada berbagai tingkat IQ siswa. Padahal IQ merupakan salah satu faktor penentu keberhasilan belajar. Andartari, Susanti, \& Andriani (2013) mengungkapkan bahwa siswa yang mempunyai tingkat intelegensi atau intelligent quotion (IQ) tinggi lebih berhasil daripada siswa yang mempunyai tingkat IQ rendah. Setiap orang mempunyai tingkat IQ yang berbeda-beda (Setiawan, 2017). Dengan demikian, tujuan dari penelitian ini yaitu meningkatkan keterampilan proses sains dan sikap ilmiah berdasarkan IQ siswa pada konsep gerak harmonik sederhana melalui model guided discovery learning berbantuan virtual lab pada materi gerak harmonik sederhana.

\section{METODE}

Metode penelitian yang digunakan yaitu quasi experiment dengan desain penelitian nonquivalent control group design. Kelompok eksperimen diberi perlakukan berupa pembelajaran dengan model guided discovery berbantuan virtual lab, sedangkan kelompok kontrol diajarkan dengan pembelajaran konvensional menggunakan direct instruction. Penelitian ini dilakukan pada tanggal 25 April sampai dengan 8 Mei 2018 di salah satu SMAN 4 Tangerang Selatan. Populasi dalam penelitian ini yaitu seluruh siswa kelas $\mathrm{X}$ SMAN 4 Tangerang Selatan. Sampel dalam penelitian yaitu siswa kelas X MIPA 1 sebagai 
kelas eksperimen dan kelas X MIPA 4 sebagai kelas kontrol. Para siswa kelas X MIPA-1 dan X MIPA-4 di bagi menjadi 3 kelompok berdasarkan tingkat IQ. Kelompok-kelompok IQ adalah kelompok IQ rendah (siswa memiliki IQ rendah), kelompok menengah (siswa memiliki IQ sedang) dan kelompok IQ tinggi (siswa memiliki IQ tinggi). Teknik pengambilan sampel menggunakan teknik purposive sampling dimana siswa yang memiliki nilai rata-rata rendah dijadikan kelas eksperimen.

Teknik pengambilan data dalam penelitian ini menggunakan teknik tes dan non tes. Teknik tes digunakan untuk mengukur KPS dalam bentuk pretest dan posttest dan IQ siswa. Teknik non tes digunakan untuk mengobservasi KPS siswa selama pembelajaran dengan model guided discovery learning berbantuan virtual lab dan memperoleh data sikap ilmiah siswa. Penelitian ini menggunakan instrumen tes dan non tes. Instrumen tes adalah tes IQ dan tes keterampilan proses sains, sedangkan instrumen non tes adalah lembar observasi keterampilan proses sains dan angket sikap ilmiah siswa, yang diisi oleh siswa.

Data yang diperoleh dianalisis menggunakan uji normalized gain dengan persamaan 1 (Coletta \& Phillips, 2005). Nilai normalized gain disimbolkan dengan $g$.

$$
g=\frac{\text { posttest-pretest }}{100-\text { pretest }}
$$

Penentuan kriteria nilai normalized gain yaitu $g<0,3$ termasuk kategori rendah; $0,3 \leq g$ $<0,7$ kategori sedang; dan $0,7 \leq g$ termasuk kategori tinggi (Hake, 1998). Uji Prasyarat menggunakan uji normalitas (uji Kolmogorov-Smornov) dan uji homogentitas (uji Levene). Uji hipotesis menggunakan uji-t dan uji Mann-Whitney dengan taraf signifikansi sebesar 5\% $(\alpha=0,05)$ (Ruseffendi, 1998).

\section{HASIL DAN PEMBAHASAN}

Sebelum memberikan perlakuan, dilakukan pretest terlebih dahulu untuk menentukan kelas eksperimen dan kontrol. Dari seluruh kelas X MIPA dengan jumlah empat kelas, Kelas X MIPA-4 mempunyai nilai rata-rata yang paling tinggi, sehingga di jadikan sebagai kelas kontrol dan X MIPA-1 dijadikan sebagai kelas eksperimen. Hasil pretest di analisis dengan uji normalitas Kolmogorov-Shapiro Wilk pada Tabel 1.

Tabel 1. Uji normalitas pretest

\begin{tabular}{ccccc}
\hline \multirow{2}{*}{ Kelompok IQ } & \multicolumn{2}{c}{ Kelas Eksperimen } & \multicolumn{2}{c}{ Kelas Kontrol } \\
\cline { 2 - 5 } & Signifikansi & Keterangan & Signifikansi & Keterangan \\
\hline Rendah & 0,200 & Normal & 0,200 & Normal \\
Sedang & 0,200 & Normal & 0,002 & Tidak normal \\
Tinggi & 0,200 & Normal & 0,200 & Normal \\
\hline
\end{tabular}

Siswa kelas eksperimen diberi perlakuan dengan model guided discovery learning berbantuan virtual lab sementara kelas kontrol menggunakan metode konvensional menggunakan direct instruction. Pada akhir pembelajaran dilakukan posttest. Hasil posttest di analisis dengan uji normalitas Kolmogorov-Shapiro Wilk yang disajikan pada Tabel 2. 
Tabel 2. Uji normalitas posttest

\begin{tabular}{ccccc}
\hline \multirow{2}{*}{ Kelompok IQ } & \multicolumn{2}{c}{ Kelas Eksperimen } & \multicolumn{2}{c}{ Kelas Kontrol } \\
\cline { 2 - 5 } & Signifikansi & Keterangan & Signifikansi & Keterangan \\
\hline Rendah & 0,200 & Normal & 0,200 & Normal \\
Sedang & 0,200 & Normal & 0,160 & Normal \\
Tinggi & 0,163 & Normal & 0,133 & Normal \\
\hline
\end{tabular}

Data pretest dan posttest kemudian di uji homogenitas dengan uji Levene menggunakan SPSS 21 yang disajikan pada Tabel 3.

Tabel 3. Uji homogenitas pretest dan posttest

\begin{tabular}{ccccc}
\hline \multirow{2}{*}{ Kelompok IQ } & \multicolumn{2}{c}{ Pretest } & \multicolumn{2}{c}{ Posttest } \\
\cline { 2 - 5 } & Signifikansi & Keterangan & Signifikansi & Keterangan \\
\hline Rendah & 0,485 & Homogen & 0,032 & Heterogen \\
Sedang & 0,052 & Homogen & 0,514 & Homogen \\
Tinggi & 0,371 & Homogen & 0,571 & Homogen \\
\hline
\end{tabular}

Data pretest dan posttest di uji kembali dengan uji hipotesis untuk mengetahui efek dari perlakuan yang diberikan. Uji hipotesis menggunakan uji parametrik yaitu uji-t dan uji non parametrik yaitu uji Mann-Whitney (U-Test). Hasil perhitungan uji hipotesis ditunjukkan pada Tabel 4.

Tabel 4. Uji hipotesis pretest dan posttest

\begin{tabular}{ccccc}
\hline \multirow{2}{*}{ Kelompok IQ } & \multicolumn{2}{c}{ Pretest } & \multicolumn{2}{c}{ Posttes } \\
\cline { 2 - 5 } & Signifikansi & Keterangan & Signifikansi & Keterangan \\
\hline Rendah & 0,321 & $\mathrm{H}_{0}$ diterima & 0,02 & $\mathrm{H}_{0}$ ditolak \\
Sedang & 0,02 & $\mathrm{H}_{0}$ ditolak & 0,00 & $\mathrm{H}_{0}$ ditolak \\
Tinggi & 0,587 & $\mathrm{H}_{0}$ diterima & 0,00 & $\mathrm{H}_{0}$ ditolak \\
\hline
\end{tabular}

Tabel 4 menunjukkan bahwa penggunaan model guided discovery learning berbantuan virtual lab dapat meningkatkan keterampilan proses sains siswa pada posttest kelompok IQ rendah, IQ sedang, dan kelompok IQ tinggi. Model pembelajaran penemuan adalah pembelajaran dimana siswa dengan secara aktif terlibat menemukan konsep dan prinsip mereka sendiri menganalisa proses untuk memecahkan masalah mereka, sehingga mereka telah belajar secara benar (Riandari, Susanti, \& Suratmi, 2018).

Model guided discovery membantu siswa memenuhi dua kriteria penting untuk pembelajaran yang efektif. Pertama, mengaktifkan atau membangun pengetahuan yang tepat untuk digunakan dalam memahami informasi baru yang masuk. Kedua, mengintegrasikan informasi baru yang masuk dengan basis pengetahuan yang tepat. (Mirasi, Osodo, \& Kibirige, 2013). Hal ini sesuai dengan hasil normalized gain keterampilan proses sains siswa. Hasil nilai normalized gain keterampilan proses sains siswa ditunjukkan pada Tabel 5. 
Tabel 5. Normalized gain keterampilan proses sains siswa

\begin{tabular}{ccccc}
\hline \multirow{2}{*}{ Kelompok IQ } & \multicolumn{2}{c}{ Eksperimen } & \multicolumn{2}{c}{ Kontrol } \\
\cline { 2 - 5 } & $\boldsymbol{g}$ & Kategori & $\boldsymbol{g}$ & Kategori \\
\hline Rendah & 0,76 & Tinggi & 0,63 & Sedang \\
Sedang & 0,76 & Tinggi & 0,51 & Sedang \\
Tinggi & 0,80 & Tinggi & 0,56 & Sedang \\
\hline
\end{tabular}

Tabel 5 menunjukkan bahwa kelas eksperimen memiliki nilai normalized gain yang lebih tinggi daripada kelas kontrol, baik pada siswa kelompok IQ rendah, kelompok IQ sedang, maupun kelompok IQ tinggi. Penggunaan model guided discovery menunjukkan peningkatan skor siswa yang signifikan dari skor yang sedang ke skor yang lebih tinggi. Penerapan model guided discovery dapat meningkatkan aktivitas belajar, meningkatkan hasil belajar, dan meningkatkan keterampilan proses sains siswa (Ningsih, Sakti, \& Rohadi, 2018).

Pengelolaan pembelajaran menggunakan virtual lab lebih efisien dibandingkan pembelajaran dengan laboratorium nyata (Syaifulloh, \& Jatmiko, 2014). Hal ini sesuai dengan hasil observasi keterampilan proses sains pada kelas eksperimen. Lebih jauh, guided discovery learning berbantuan virtual lab dapat digunakan untuk mereduksi miskonsepsi (Habibbulloh et al., 2017). Beberapa software virtual lab yang dapat digunakan diantaranya Phet (Alatas et al., 2018) dan LabVIEW (Abdulwahed \& Nagy, 2013; Tong-on, Saphet, \& Thepnurat, 2017).

Tabel 6. Observasi keterampilan proses sains siswa kelas eksperimen

\begin{tabular}{lcc}
\multicolumn{1}{c}{ Aspek KPS } & Presentase (\%) & Kesimpulan \\
\hline Berhipotesis & 74,99 & Baik \\
Merencanakan Percobaan & 80,55 & Baik \\
Mengamati & 78,23 & Baik \\
Mengklasifikasi & 79,16 & Baik \\
Berkomunikasi & 81,96 & Baik \\
Mengajukan Pertanyaan & 86,11 & Sangat Baik \\
\hline \multicolumn{1}{r}{ Rata-rata } & $\mathbf{8 0 , 1 6}$ & Baik \\
\hline
\end{tabular}

Tabel 6 menunjukkan bahwa berdasarkan hasil observasi, keterampilan proses sains siswa pada kelas eksperimen berkategori baik (80,16\%). Aspek KPS terendah yaitu berhipotesis. Oleh karena itu, kegiatan berhipotesis dalam pembelajaran harus sering dilakukan. Wulandari, Sa'dijah, As'ari, \& Rahardjo (2018) menyatakan bahwa langkahlangkah guided discovery learning yaitu mencakup stimulation, problem statement, data collection, data processing, verification dan generalization. Pada tahap problem statement dan data collection, memungkinkan siswa untuk merumuskan dan membuktikan hipotesis mereka, apakah benar atau salah. Nilai yang rendah pada aspek berhipotesis bisa disebabkan siswa masih bingung dalam merumuskan hipotesis yang harus diuji. Penerapan discovery learning memungkinkan siswa lebih aktif, kreatif dan inovatif dalam mencari dan memecahkan masalah (Suyanti \& Purba, 2017). 
Selain data observasi, data angket sikap ilmiah yang diisi oleh siswa menunjukkan bahwa sikap ilmiah siswa berkategori baik $(86,11 \%)$. Hasil analisis data angket sikap ilmiah siswa ditunjukkan pada Tabel 7.

Tabel 7. Observasi sikap ilmiah siswa

\begin{tabular}{|c|c|c|c|c|c|c|}
\hline \multirow{2}{*}{ Aspek Sikap Ilmiah } & \multicolumn{2}{|c|}{ IQ Rendah } & \multicolumn{2}{|c|}{ IQ Sedang } & \multicolumn{2}{|c|}{ IQ Tinggi } \\
\hline & $\%$ & Kategori & $\%$ & Kategori & $\%$ & Kategori \\
\hline Sikap ingin tahu & 80,28 & Baik & 81,11 & Baik & 82,39 & Baik \\
\hline Respek terhadap data & 80,9 & Baik & 80,39 & Baik & 81,54 & Baik \\
\hline Berpikir kritis & 80,54 & Baik & 81,54 & Baik & 87,28 & Sangat Baik \\
\hline $\begin{array}{l}\text { Sikap penemuan dan } \\
\text { kreativitas }\end{array}$ & 82,39 & Baik & 84,28 & Baik & 87,54 & Sangat Baik \\
\hline $\begin{array}{l}\text { Berpikir terbuka dan } \\
\text { kerjasama }\end{array}$ & 83,54 & Baik & 87,11 & Sangat Baik & 87,39 & Sangat Baik \\
\hline Ketekunan & 82,74 & Baik & 82,28 & Baik & 87,11 & Sangat Baik \\
\hline $\begin{array}{l}\text { Peka terhadap lingkungan } \\
\text { sekitar }\end{array}$ & 83,11 & Baik & 80,9 & Baik & 89,54 & Sangat Baik \\
\hline Rata-rata & 81,93 & Baik & 82,52 & Baik & 86,11 & Sangat Baik \\
\hline
\end{tabular}

Sikap ilmiah dapat mempengaruhi hasil belajar siswa, dan dapat meningkatkan afektif dan psikomotor siswa (Istiqomah, Prasojo, \& Arifa'I, 2018). IQ berkontribusi 57,7\% terhadap hasil belajar siswa (Tias, Istamar, \& Corebima, 2015). Berdasarkan Tabel 7 menunjukkan bahwa sikap ilmiah siswa berkategori sangat baik pada siswa kelompok IQ tinggi $(86,11 \%)$. Kelompok siswa dengan IQ rendah dan sedang menunjukkan sikap ilmiah paling tinggi pada aspek berpikir terbuka dan bekerja sama sedangkan kelompok IQ tinggi yaitu dan pada aspek sikap penemuan serta kreativitas. Hal ini senada dengan penelitian Putri, Suyanto, \& Subali (2016) yang menyatakan bahwa IQ berkorelasi dengan kemampuan berpikir divergen yaitu kreativitas. Dengan demikian, IQ yang baik dan terlaksananya pembelajaran guided discovery berbantuan virtual laboratory dapat meningkatkan prestasi akademik siswa dalam hal ini yaitu KPS dan sikap ilmiah.

\section{SIMPULAN DAN SARAN Simpulan}

Penggunaan model guided discovery learning berbantuan virtual lab dapat meningkatkan keterampilan proses sains dan sikap ilmiah siswa pada setiap kelompok IQ (kelompok IQ rendah, sedang, dan tinggi) pada konsep gerak harmonik sederhana. Berdasarkan observasi, keterampilan proses sains siswa tertinggi yaitu aspek mengajukan pertanyaan dan rendah pada aspek berhipotesis. Kelompok siswa dengan IQ rendah dan sedang menunjukkan sikap ilmiah paling tinggi pada aspek berpikir terbuka dan bekerja sama sedangkan kelompok IQ tinggi yaitu dan pada aspek sikap penemuan serta kreativitas. Dengan demikian, model guided discovery berbantuan virtual lab dapat meningkatkan keterampilan proses sains siswa pada seluruh kelompok IQ.

\section{Saran}

Penerapan model guided discovery learning berbantuan virtual lab membutuhkan manajemen waktu yang baik agar semua langkah-langkah dalam pembelajaran dapat terlaksana dengan tepat waktu. Penerapan model guided discovery learning berbantuan virtual 
lab dapat menjadi salah satu alternatif model pembelajaran yang dapat diterapkan oleh guru pada konsep fisika yang berbeda.

\section{DAFTAR PUSTAKA}

Abdulwahed, M., \& Nagy, Z. K. (2013). Developing the TriLab , a triple access mode (handson, virtual, remote) laboratory, of a process control rig using LabVIEW and Joomla. Comput. Appl. Eng. Educ, 21, 614-626. https://doi.org/10.1002/cae.20506

Akinbobola, A. O., \& Afolabi, F. (2010). Constructivist practices through guided discovery approach: The effect on students' cognitive achievements in Nigerian senior secondary school physics. Eurasian Journal of Physics and Chemistry Education, 2(1), 16-25.

Al-Fajri, M. H., Alatas, F., \& Daryono, Da. (2016). Seminar Nasional Pendidikan IPABiologi FITK UIN Syarif Hidayatullah Jakarta, 28 September 2016. In Seminar Nasional Pendidikan IPA-Biologi FITK UIN Syarif Hidayatullah Jakarta, 28 September 2016 (pp. 127-133).

Alatas, F., Pohan, H., \& Sulukin Nisa, A. (2018). The Implemention of virtual laboratory Phet guided discovery learning on students achievement: Dynamic electricity topic. Advances in Social Science, Education and Humanities Research, 115(Icems 2017), 61-65. https://doi.org/10.2991/icems-17.2018.13

Andartari, A., Susanti, S., \& Andriani, V. (2013). Pengaruh kemampuan intelektual (IQ) dan motivasi belajar terhadap hasil belajar siswa pada mata pelajaran akuntansi pada SMA Labschool Rawamangun. Jurnal Pendidikan Ekonomi Dan Bisnis, 1(1), 1-24.

Astra, I. M., \& Wahidah, R. S. (2017). Peningkatan keterampilan proses sains siswa melalui model guided discovery learning kelas XI MIPA pada materi suhu dan kalor. Jurnal Penelitian \& Pengembangan Pendidikan Fisika, 3(2), 181-190. https://doi.org/10.21009/1.03209

Bajpai, M., \& Kumar, A. (2015). Effect of virtual laboratory on students' conceptual achievement in physics. International Journal of Current Research, 7(02), 1280812813.

Coletta, V. P., \& Phillips, J. A. (2005). Interpreting FCI scores: Normalized gain, preinstruction scores, and scientific reasoning ability. American Journal of Physics, 73(12), 1172-1182. https://doi.org/10.1119/1.2117109

Dewi, V. P., Doyan, A., \& Soeprianto, H. (2017). Pengaruh model penemuan terbimbing terhadap keterampilan proses sains ditinjau dari sikap ilmiah pada pembelajaran IPA. Jurnal Penelitian Pendidikan IPA, 3(1), 60-67. https://doi.org/10.29303/jppipa.v3i1.102

Habibbulloh, M., Jatmiko, B., \& Widodo, W. (2017). Pengembangan perangkat pembelajaran model guided discovery berbasis lab virtual untuk mereduksi miskonsepsi siswa SMK topik efek fotolistrik. Jurnal Penelitian Fisika Dan Aplikasinya (JPFA), 7(1), 27-43.

Hake, R. (1998). Interactive-engagement versus traditional methods : a six-thousand-student survey of mechanics test data for introductory physics courses. American Journal of Physics, 66(1), 64-74.

Handayani, B. T., Arifuddin, M., \& Misbah, M. (2017). Meningkatkan keterampilan proses sains melalui model guided discovery learning. Jurnal Ilmiah Pendidikan Fisika, 1(3), 143-154. https://doi.org/10.20527/jipf.v1i3.1016

Hannasari, R., Harahap, M. B., \& Sinulingga, K. (2017). The effect of scientific inquiry learning model and creative thinking skills on student's science process skills. Journal of Education, 8(21), 48-52. https://doi.org/10.9790/7388-0704035557

Hariyanto, A. (2016). Pengaruh discovery learning berbantuan paket program simulasi Phet terhadap prestasi belajar fisika. Jurnal Pendidikan Dan Kebudayaan, 1(3), 365. 
https://doi.org/10.24832/jpnk.v1i3.321

Haryati, H., Manurung, B., \& Gultom, T. (2017). The effect of learning model on higher order thinking and student science process skills in Ecology. International Journal of Humanities, Social Sciences and Education, 4(10), 150-155. https://doi.org/10.20431/2349-0381.0410018

Hayati, D. P., Bintari, S. H., \& Sukaesih, S. (2018). Implementation of the practicum methods with guided-discovery model to the student skill of science process. Journal of Biology Education, 7(1), 118-126. https://doi.org/10.15294/jbe.v7i1.23005

Hermansyah, H., Gunawan, G., Harjono, A., \& Adawiyah, R. (2019). Guided inquiry model with virtual labs to improve students ' understanding on heat concept. Journal of Physics: Conference Series, (1153 012116), 1-5. https://doi.org/10.1088/1742$6596 / 1153 / 1 / 012116$

Hidayatulloh, M. (2015). Pengembangan perangkat pembelajaran inkuiri terbimbing berorientasi kurikulum 2013 dengan melatihkan keterampilan proses sains pada materi pengukuran. Jurnal Inovasi Pendidikan Fisika, 04(02), 92-97.

Hussin, A. A. (2018). Education 4.0 made simple: Ideas for teaching. International Journal of Education and Literacy Studies, 6(3), 92-98.

Iradat, R. D., \& Alatas, F. (2017). The implementation of problem-solving based laboratory activities to teach the concept of simple harmonic motion in senior high school. Journal of Physics: Conference Series, 895(1), 1-7. https://doi.org/10.1088/17426596/895/1/012014

Istiqomah, R., Prasojo, L. D., \& Arifa'I, A. M. (2018). Improving senior high school student's creativity using discovery learning model in islamic senior high school 1 Jambi city. European Journal of Multidisciplinary Studies, 109. https://doi.org/http://dx.doi.org/10.26417/ejms.v7i2.p108-115

Liao, Y., Loures, E. R., Deschamps, F., Brezinski, G., \& Venâncio, A. (2018). The impact of the fourth industrial revolution: A cross-country/region comparison. Producao, 28, 1-18. https://doi.org/10.1590/0103-6513.20180061

Maharani, B. Y., \& Hardini, A. T. A. (2017). Penerapan model pembelajaran discovery learning berbantuan benda konkret untuk meningkatkan hasil belajar IPA. E-Jurnal Mitra Pendidikan, 1(5), 549-561. https://doi.org/10.1017/CBO9781107415324.004

Malinda, S., Rohadi, N., \& Medriati, R. (2017). Penerapan model discovery learning untuk meningkatkan sikap ilmiah dan hasil belajar kognitif siswa pada konsep usaha dan energi di kelas X MIPA-3 SMAN 10 Bengkulu. Jurnal Pembelajaran Fisika, 1(1), 56-63.

Miftah, M. (2016). Pengembangan perangkat pembelajaran berorientasi metode penemuan terbimbing dalam Pencapaian keterampilan proses sains dan keterampilan berpikir kritis peserta didik MAN 2 model Makassar. JPFT (Jurnal Pendidikan Fisika Tadulako Online), 4(1), 63. https://doi.org/10.22487/j25805924.2016.v4.i1.5505

Mirasi, W., Osodo, J., \& Kibirige, I. (2013). Comparing guided discovery and expositionwith-interaction methods in teaching biology in secondary schools. Mediterranean Journal of Social Sciences, 4(14), 81-87. https://doi.org/10.5901/mjss.2013.v4n14p81

Ningsih, A. A. W., Sakti, I., \& Rohadi, N. (2018). Penerapan model penemuan terbimbing untuk meningkatkan keterampilan proses sains dan hasil belajar siswa di SMAN 1 Kota Bengkulu. Jurnal Kumparan Fisika, 1(1), 22-29. https://doi.org/10.33369/jkf.1.1.22-29

Nuzulia, N., Adlim, A., \& Nurmaliah, C. (2017). Relevansi kurikulum dan keterampilan proses sains terintegrasi mahasiswa kimia, fisika, biologi dan matematika. Jurnal Pendidikan Sains Indonesia, 5(1), 120-126.

Price, C. B., \& Price-mohr, R. (2019). PhysLab : a 3D virtual physics laboratory of simulated experiments for advanced physics learning. Journal of Physics: Conference Series, (54 035006), 1-9. 
Putri, R. P., Suyanto, S., \& Subali, B. (2016). Hubungan intelegensi dengan kemampuan berpikir divergen keterampilan proses sains siswa sekolah dasar di DIY. Jurnal Pendidikan Biologi, 5(5), 59-70.

Rahayu, N. H., \& Admoko, S. (2016). Penerapan model pembelajaran guided discovery untuk melatihkan keterampilan proses sains siswa pada materi fluida statis di kelas X SMA negeri 1 Waru Sidoarjo. Jurnal Inovasi Pendidikan Fisika, 05(01), 132-27.

Ramayanti, S., Utari, S., \& Saepuzaman, D. (2017). Training students' science process skills through didactic design on work and energy. Journal of Physics: Conference Series, 895(1). https://doi.org/10.1088/1742-6596/895/1/012110

Ranjan, A. (2017). Effect of virtual laboratory on development of concepts and skills in physics. International Journal of Technical Research \& Science, 2(1), 15-21.

Riandari, F., Susanti, R., \& Suratmi. (2018). The influence of discovery learning model application to the higher order thinking skills student of Srijaya Negara Senior High School Palembang on the animal kingdom subject matter The influence of discovery learning model application to the higher order. Journal of Physics: Conference Series, 1022(012055), 1-8. https://doi.org/doi :10.1088/1742-6596/1022/1/012055

Rismawati, R., Sinon, I. L. S., Yusuf, I., \& Widyaningsih, S. W. (2017). Penerapan model pembelajaran inkuiri terbimbing (guided inquiry) terhadap keterampilan proses sains peserta didik di SMK Negeri 02 Manokwari. Lectura : Jurnal Pendidikan, 8(1), 12-25.

Ruseffendi. (1998). Statistika dasar untuk penelitian pendidikan. Bandung: IKIP Bandung Press.

Sahhyar, S., \& Nasution, F. H. (2017). The Effect of Scientific Inquiry Learning Model Based on Conceptual Change on Physics Cognitive Competence and Science Process Skill ( SPS ) of Students at Senior High School. Journal of Education and Practice, 8(5), 120126. https://doi.org/10.1088/0067-0049/219/2/34

Sari, P. I., Gunawan, G., \& Harjono, A. (2016). Penggunaan discovery learning berbantuan laboratorium virtual pada penguasaan konsep fisika siswa. Jurnal Pendidikan Fisika Dan Teknologi, 2(4), 176. https://doi.org/10.29303/jpft.v2i4.310

Setiawan, A. (2017). Pengaruh kemampuan analisis terhadap prestasi belajar matematika ditinjau dari intellegent quotion (IQ). NUMERICAL (Jurnal Matematika Dan Pendidikan Matematika), 1(1), 25-34. https://doi.org/10.25217/numerical.v1i1.120

Siswono, H. (2017). Analisis pengaruh keterampilan proses sains terhadap penguasaan konsep fisika siswa. Momentum: Physics Education Journal, 1(2), 83-90. https://doi.org/10.21067/mpej.v1i2.1967

Susilaningrum, D. F., Santosa, S., \& Ariyanto, J. (2017). Studi Komparasi Antara Penerapan Model Learning Cycle 5E dan Discovery Learning terhadap Capaian Keterampilan Proses Sains dan Hasil Belajar Kognitif Pada Siswa Kelas X SMA Negeri 3 Boyolali Comparative Study Between the Application of Learning Cycle 5E a. Proceeding Biology Education Conference, 14(1), 331-339.

Suyanti, R. D., \& Purba, D. M. (2017). The implementation of discovery learning model based on lesson study to increase student's achievement in colloid. AIP Conference Proceedings, 1823, 1-9. https://doi.org/10.1063/1.4978163

Syaifulloh, R. B., \& Jatmiko, B. (2014). Penerapan pembelajaran dengan model guided discovery dengan lab virtual PhET untuk meningkatkan hasil belajar siswa kelas XI di SMAN 1 Tuban pada pokok bahasan teori kinetik gas. Jurnal Inovasi Pendidikan Fisika (JIPF), 03(02), 174-179. https://doi.org/https://doi.org/10.1063/1.4978163

Tias, P. A., Istamar, S., \& Corebima, A. D. (2015). The contribution of intelligence quotient (IQ) on biology academic achievement of senior high school students in Medan, Indonesia. International Journal of Educational Policy Research and Review, 2(10), 141-147. https://doi.org/http://dx.doi.org/10.15739/IJEPRR.023 
Tong-on, A., Saphet, P., \& Thepnurat, M. (2017). Simple harmonics motion experiment based on LabView interface for Arduino. Journal of Physics: Conference Series, (901 012114), $1-6$.

Wulandari, A., Sa'dijah, C., As'ari, A. R., \& Rahardjo, S. (2018). Modified guided discovery model : A conceptual framework for designing learning model using guided discovery to promote student's analytical thinking skills. Journal of Physics: Conference Series, 1028 $01215,1-9$.

Wulandari, E., Suliyanah, \& Rohmawati, L. (2017). Pengembangan lembar kerja siswa (LKS) berbasis inkuiri terbimbing untuk melatihkan keterampilan proses sains pada pokok bahasan hukum Newton di SMA Negeri 1 Driyorejo. Jurnal Inovasi Pendidikan Fisika, 06(03), 258-264.

Zeidan, A. H., \& Jayosi, M. R. (2015). Science process skills and attitudes toward science among Palestinian secondary school students. World Journal of Education, 5(1), 13-24. https://doi.org/10.5430/wje.v5n1p13

Zunita, P. O., Dewi, H., \& Giarti, S. (2018). Efektifitas model discovery learning dan guided discovery ditinjau dari ketrampilan pemecahan masalah matematika terhadap hasil belajar kelas 4 Dabin 2 dan 3 Kecamatan Godong-Grobogan. Journal for Lesson and Learning Studies, 1(3), 268-278. https://doi.org/10.23887/jlls.v1i3.15013

\section{PROFIL SINGKAT}

Fathiah Alatas, lahir di Jakarta, 15 Februari 1983, meraih gelar Sarjana Pendidikan (S.Pd) pada tahun 2004 di Institut Agama Islam Negeri Sunan Gunung Djati Bandung dan Magister (M.Si) jurusan Fisika di Institut Teknologi Sepuluh November Surabaya (ITS) pada tahun 2008. Saat ini bekerja sebagai dosen di jurusan Pendidikan Fisika FITK Universitas Islam Negeri Syarif Hidayatullah Jakarta. Email: fathiah.alatas@uinjkt.ac.id

Willa Hikma Sakina, lahir di Jakarta, 06 Januari 1994, meraih Gelar Sarjana Pendidikan (S.Pd) di Universitas Islam Negeri Syarif Hidayatullah Jakarta, Fakultas Ilmu Tarbiyah dan Keguruan, Jurusan Pendidikan Ilmu Pengetahuan Alam, Program Studi Pendidikan Fisika pada tahun 2019. 